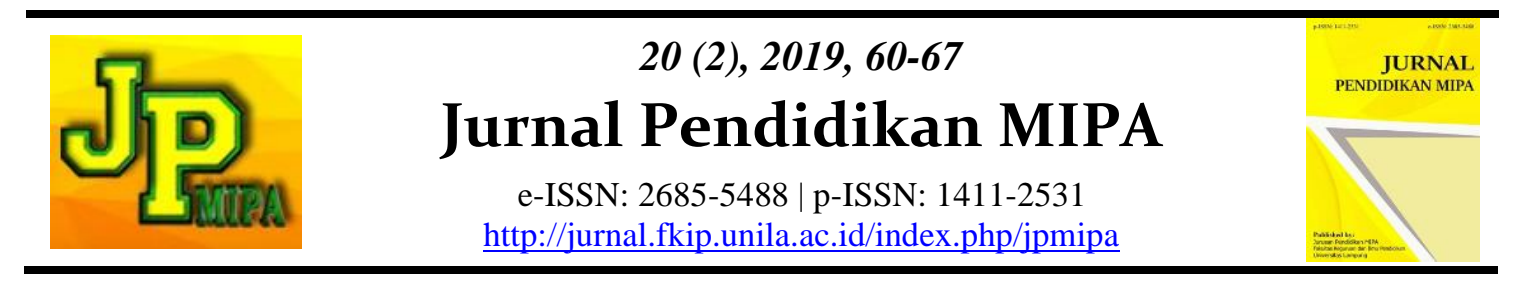

\title{
The Ability of Students' Mathematical Proof in An Introduction to Group Theory in terms of Gender Differences
}

\author{
Sugeng Sutiarso \\ Department of Mathematics Education, Faculty of Teacher Training and Education, University of \\ Lampung, Indonesia
}

\begin{abstract}
Mathematical proof is one of the mathematical abilities that is very important for students. Until now, most students had difficulty in mathematical proof. The difficulty of this mathematical proof needs to be analyzed the causes, including analysis based on gender differences. This qualitative research aims to describe the ability of mathematical proof based on gender difference. The research subjects were students of mathematics education FKIP Lampung University taking the introduction to group theory in the odd semester of the academic year 2019/2020. Research subjects were 30 people; consisted of 7 men and 23 women. Data was collected through tests and observations, and it were analyzed descriptively based on 3 indicator levels, namely fluency, flexibility, and originality. The results showed that the mathematical proof ability of students were 1.80 (medium); men was 1.43 (medium) and female was 1.87 (medium), and men reach originality. It is concluded that the mathematical proof ability of students is medium, women are higher than men in fluency and flexibility, but men are higher than women in originality.
\end{abstract}

Keywords: mathematical proof, the introduction to group theory, gender differences.

Abstrak: Pembuktian matematis adalah salah satu kemampuan matematis yang sangat penting bagi siswa. Hingga saat ini, sebagian besar siswa mengalami kesulitan dalam pembuktian matematis. Kesulitan pembuktian matematis ini perlu dianalisis penyebabnya, termasuk analisis berdasarkan perbedaan jenis kelamin. Penelitian kualitatif ini bertujuan untuk mendeskripsikan kemampuan pembuktian matematis berdasarkan perbedaan jenis kelamin. Subjek penelitian adalah mahasiswa pendidikan matematika FKIP Universitas Lampung yang menempuh kuliah teori grup pada semester ganjil tahun akademik 2019/2020. Subjek penelitian berjumlah 30 orang; terdiri dari 7 laki-laki dan 23 perempuan. Data dikumpulkan melalui tes dan observasi, dan datanya dianalisis secara deskriptif berdasarkan 3 level indikator, yaitu fluency, flexibility, dan originality. Hasil penelitian menunjukkan bahwa kemampuan pembuktian matematis mahasiswa adalah 1,80(sedang); laki-laki adalah 1,43 (sedang) dan perempuan adalah 1,87 (sedang), dan laki-laki yang mencapai indikator originality. Jadi, diperoleh kesimpulan bahwa kemampuan pembuktian matematis mahasiswa tergolong sedang, perempuan lebih tinggi dibandingkan laki-laki pada fluency dan flexibility, namun laki-laki lebih tinggi daripada perempuan pada originality.

Kata kunci: pembuktian matematis, pengantar teori grup, perbedaan jenis kelamin.

Sugeng Sutiarso

Email: sugeng.sutiarso@fkip.unila.ac.id
DOI: http://dx.doi.org/10.23960/jpmipa/v20i2.pp60-67

Received: 25 November 2019

Accepted: 27 December 2019 


\section{- INTRODUCTION}

Mathematics is one of the fields of science taught to students from elementary school to tertiary level. The study of material at the elementary school level is very simple, and the study of the material develops more complexly up to college. In addition to the study of the material, the abilities students want to achieve also develop in accordance with the nature of mathematics itself. Soedjadi (2000) stated that science which is abstract, relies on agreement, has a deductive mindset, has symbols that are empty of meaning, pays attention to the universe of speech, and is consistent with its system. Rochmad (2010) added that deductive mindset is a form of mathematical proof because deductive mindset is developed through mathematical proof. Generally, the proof of mathematics at the elementary school level uses the inductive mindset, while the proof at the college level uses the deductive mindset. In addition, Sari (2016) stated that a deductive mindset is more difficult for students than an inductive mindset; or in other words deductive proof is more difficult for students than inductive proof. Usually, mathematical proof at higher education level is more widely used than the lower level (elementary and secondary schools).

Mathematical proof is one of the mathematical abilities that is very important for students, in addition to understanding mathematical concepts, solving problems, and communicating mathematical ideas. Stefanowicz (2014) stated a proof is a sequence of logical statements, one implying another, which gives an explanation of whya given statement is true. Mathematical proof is absolute, which means that once a theorem is proved, it is proved for ever. Until proventhough, the statement is never accepted as a true one. There are two techniques that can be used to prove the statements, that is direct proofs and indirectproofs. Direct proof assumes a given hypothesis, or any other known statement, and then logicallydeduces a conclusion. Indirect proof, also called proof by contradiction, assumes the hypothesis (if given) together with a negation of a conclusion to reach the contradictory statement. In fact, to date most students have difficulty in mathematical proof.

Some studies report the cause of the difficulty of students doing mathematical proof. Maya \& Sumarmo (2011) reported several causes of student difficulties in mathematical proof, namely unable to generate an example, unable to explain a concept into simpler form of concepts, did not understand standard mathematical notation and mathematical language, did not know to start a proof, did not satisfy for starting a proof, and lack of understanding toward mathematical notation caused they used unexact or confusing mathematical language. Santosa (2013) stated five reasons students find it difficult to carry out mathematical proof, namely lack of understanding of concepts, lack of logical knowledge and methods of proof, limitations of students in understanding language and mathematical notation, ability and knowledge of choosing facts and theorems to be applied, and affective aspects of belief in proof. Nurrahmah \& Karim (2018) stated the cause of students' difficulty in mathematical proof due to weak understanding of concepts. Based on the three results of the study it can be concluded that the understanding of weak mathematical concepts is the main cause of the difficulty of students doing mathematical proof.

The difficulty of students in mathematical proof is expressed by the weak achievement of mathematical proof indicators. Lestari (2015) listed that the five indicators of mathematical proof ability are reading, doing, criticizing, modifying, and rearranging mathematical proof directly or indirectly. Herizal et al., (2019) provide 3 indicators of mathematical proof, namely (1) understanding the axioms, premises, and 
mathematical results that already exist with the flow of deductive reasoning, (2) completing the proof if there are errors, and (3) comparing the effectiveness of one evidence with another evidence. According to Sutiarso et al., (2019) that indicators of mathematical proof ability can use indicators of creative thinking ability, namely fluency, flexibility, and originality; and this indicator is used in this study.

At present, research on mathematical proof ability in terms of gender differences is rarely (if ever) conducted. While research on other mathematical abilities have (often even) done by researchers such as mathematical problem-solving ability (Zhu, 2007; Lowrie \& Diezmann, 2011), mathematics literacy (Thlen, 2016; Aula et al., 2019), mathematical disposition (Birenbaum \& Nasser, 2006; Andari \& Sugiman, 2019), understanding of mathematical concepts (Wilhelm, 2009; Sutiarso et al., 2018), mathematical creative thinking (He \& Wong, 2011; Mahama et al., 2019), mathematical reasoning (Halat, 2008; Erdem \& Soylu, 2017), and mathematical representation (Fauzan et al., 2018). Research on students' mathematical proof in terms of gender differences is seen as important. The results of some of these studies indicate that there are differences in mathematical thinking skills between men and women. The results of this study can also be a lecturer guide in teaching mathematics between male and female students. especially mathematical proof in the introduction to group theory. This study aims to describe the mathematical proof ability of students in the introduction to group theory courses in terms of gender differences.

\section{METHOD}

This type of research is qualitative which explains the actual situation without any treatment of the research subjects. The research subjects were students of mathematics education, Faculty of Teacher Training and Education, Lampung University taking the introduction to group theory in the odd semester of the academic year 2019/2020. Research subjects were 30 people; consisted of 7 men and 23 women. Data was collected through tests and observations, and it were analyzed descriptively based on 3 indicator levels, namely fluency, flexibility, and originality. The form of test is essay from introductory material to group theory, that is (1) prove the division algorithm "Let $a$ and $b$ be integers $(b>0)$. Then there are integers $q$ and $r$ which are valid single $a=b q$ $+\mathrm{r}, 0 \leq \mathrm{r}<\mathrm{b}$, dan $(2)$ prove that $22^{\mathrm{k}+1}+(-1)^{\mathrm{k}} .8 \equiv 0(\bmod 5)$ ?. The selection of this problem is based on the consideration that most of the material (more than $80 \%$ ) contains proofs of theorems/theorems. Observation to analyze student answers based on students' answers to the introduction of group theory

\section{RESULT AND DISCUSSION}

The results of this study are based on students' answers to the introduction of group theory. The students' answers were analyzed based on 3 indicators of mathematical proof ability, namely fluency, flexibility, and originaly. Each student's answer was analyzed based on gender and each indicator of mathematical proof ability. The results of the analysis of the mathematical proof ability of students from 30 students as follow in Figure 1. 


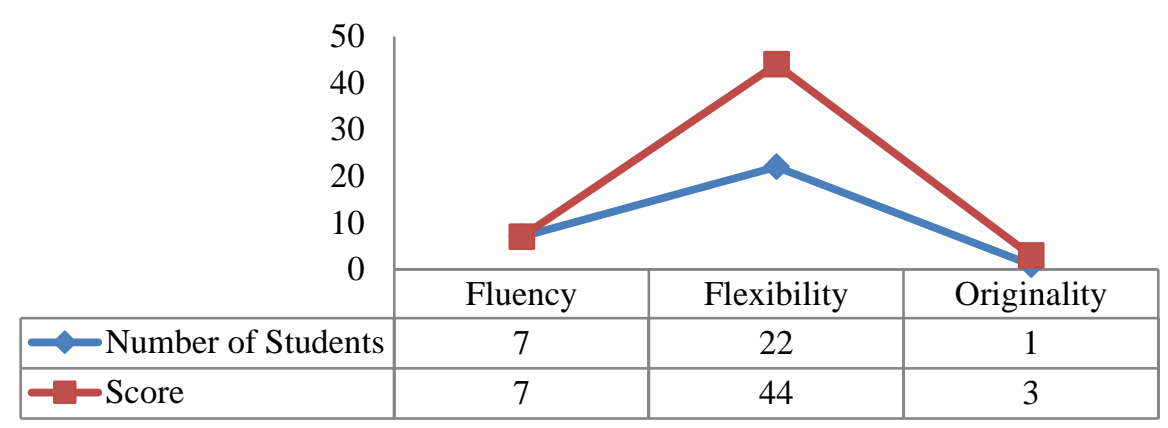

Figure 1. Students' mathematical proof ability in an introduction to group theory

Based on Figure 1, it was found that the mathematical proof ability of students in introduction to group theory mostly achieved fluency and flexibility indicators, and originality were the least indicators obtained by students. These results indicate that the mathematical proof ability of students medium level. Then, the results of the analysis of the mathematical proof ability of students from 30 students in terms of gender differences as in Figure 2.

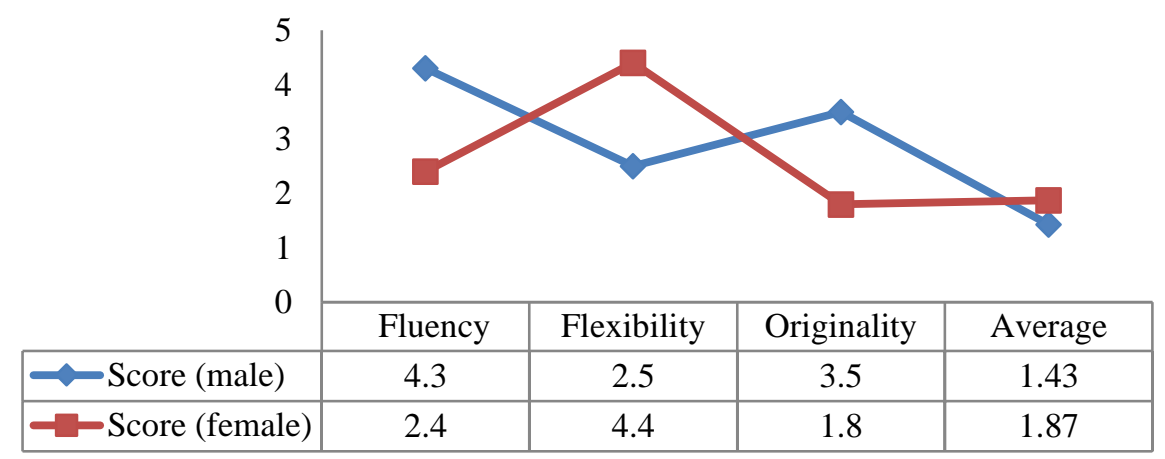

Figure 2. Students' mathematical proof ability in terms of gender differences

Based on Figure 2, it is found that the mathematical proof ability of female is higher than that of men, even though the two levels of proof ability between the two are the same (medium). Besides that, from Table 3 it was found that more men achieved fluency and women achieved more flexibility, but only men achieved originality and women did not achieve it. It can be concluded that the mathematical proof ability of women is higher than that of men, although there are men who reach originality.

The results of research on mathematical proofing ability of mathematics education students in the introduction to group theory showed that most students achieved fluency and flexibility, and only 1 person achieved originality. The result is an analysis of the students' answers to the introduction of group theory questions consist of 2 items, namely (1) prove the division algorithm "Let $a$ and $b$ be integers ( $b>0)$. Then there are integers $\mathrm{q}$ and $\mathrm{r}$ which are valid single $\mathrm{a}=\mathrm{bq}+\mathrm{r}, 0 \leq \mathrm{r}<\mathrm{b}$, dan (2) prove that $22^{\mathrm{k}+1}+(-$ 1) ${ }^{\mathrm{k}} .8 \equiv 0(\bmod 5)$ ?. When analyzing student answers, for question number 1 most students were limited to solving fluency. This is evidenced by the answers of students who tend to follow what is written in the textbook or what is exemplified by the lecturer. The answers of students in this number 1 (Figure 3), there is no flexibility even originality. The following is an example of student answer number 1, namely: 


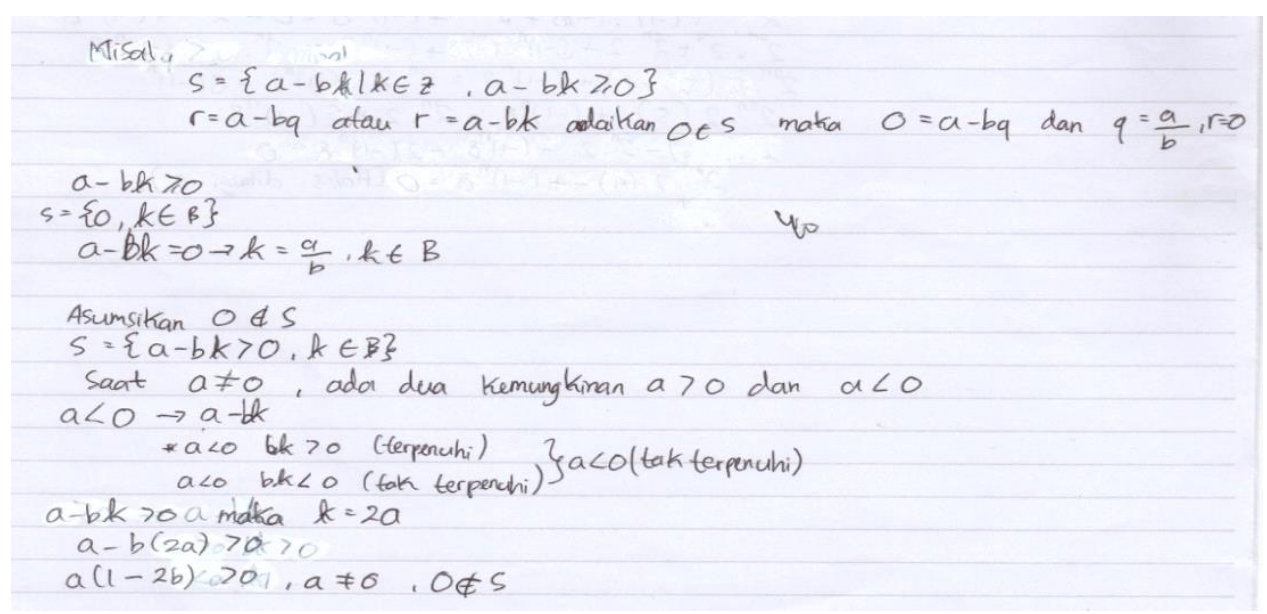

Figure 3. Example of students' answers on number 1

Furthermore, in answer number 2 it appears that students achieve flexibility. This is indicated by the existence of different student answer ideas from textbooks or lecturer examples. The following is an example of one student's answer number 2 (Figure 4). Based on student answers to number 2 shows that students are not only fluency in solving problems, but also students achieve flexibility indicators. Flexibility can be demonstrated when students modify algebraic operations in proving $\mathrm{k}=\mathrm{n}+1$. The completion of this proof is not easy, because students must be able to associate an algebraic concept and operation with other algebraic concepts and concepts. This shows that flexibility is achieved by students.

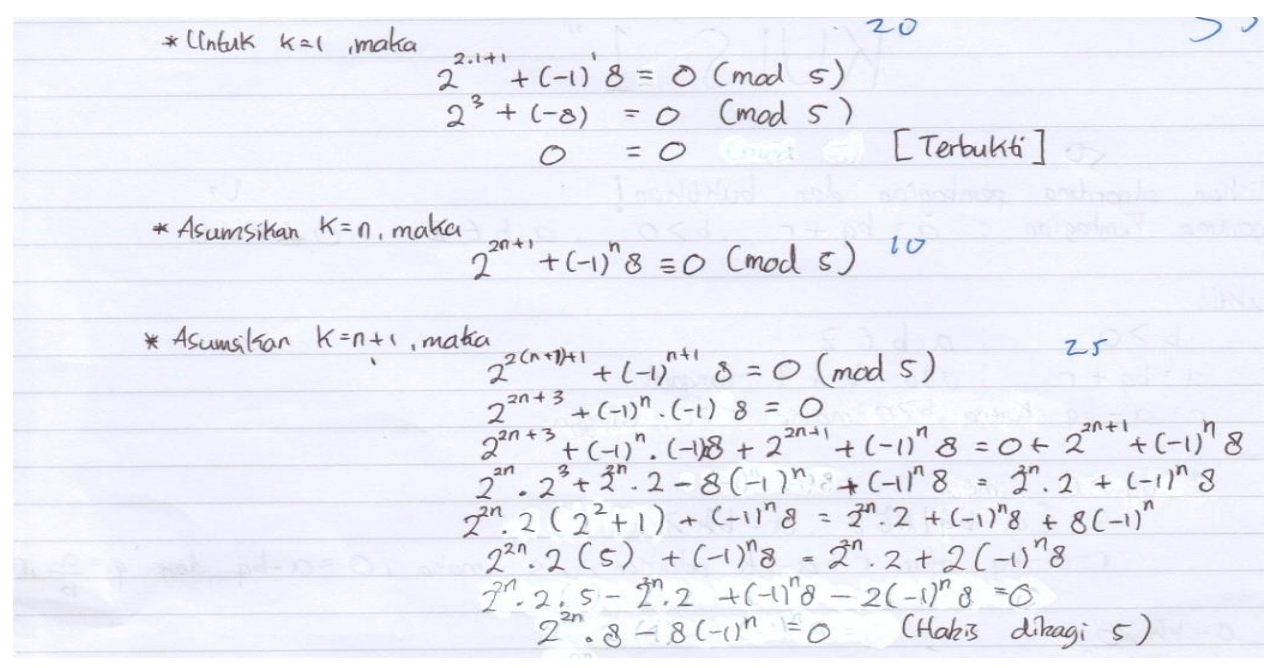

Figure 4. Example of students' answers on number 2

The results also showed that there were differences in mathematical proof ability between men and women; and the difference is that female students have the ability to prove higher than men. In the first two indicators (fluency and flexibility) women are higher than men but in the third indicator (originality) only male students achieve it. The results of the analysis of the test answers show that women are more systematic and detailed in proof than men, but the answers of women are still limited to imitating or 
slightly modifying examples of lecturer proof. However, the results of the analysis on the students' answers showed that there was a male student who answered the difference in mathematical proof ability between men and women. The results of this data analysis are in accordance with the opinion (Baer \& Kaufman, 2008) which states that women are more creative (fluent and flexible) in completing work/problems than men.

With regard to higher male students than female indicators of originality, this is caused by differences in differences between women and men can also be caused by differences in the anatomy of male and female brains. According to Snowman \& McCown (2012) that differences in brain structure have a significant effect on differences in the abilities of men and women. The brain structure of men causes men to tend to have a higher level of self-confidence than women. With this higher level of trust, men are braver to convey original / new ideas than women; while women are often hesitant to come up with new ideas. There are differences in the results of this study with previous studies. A meta-analysis study by Cramond et al., (2005) states that from various studies on creativity found a relationship between gender differences with the level of creativity both in terms of quantity and quality. The results of an analysis of research journals from 1958-1998 found a difference both in the aspects of fluency, flexibility, and originality. Women tend to be higher in the aspects of fluency, originality, and elaboration, while in the aspect of flexibility men tend to be higher even though the difference is not too high. Although there are differences with the previous research, but there are similarities in this study, namely indicators of fluency. That in this study it was found that women were higher than men on the fluency indicator. The difference between this study and the previous one is due to the small number of subjects of this study compared to the meta-analyzes of previous studies.

\section{CONCLUSION}

Based on the results of the study concluded that the mathematical proof ability of students in introduction to group theory mostly achieved fluency and flexibility indicators, and originality were the least indicators obtained by students; these results indicate that the mathematical proof ability of students medium level. In addition, the mathematical proof ability of female is higher than that of men, even though the two levels of proof ability between the two are the same (medium); that is women are higher than men in fluency and flexibility, but men are higher than women in originality. Based on the results of this study, further research is needed on how to improve mathematical proof ability for male and female students including other mathematics' material.

\section{REFERENCES}

Andari, I. E. \& Sugiman. (2019). Is there any interaction effects of students' gender and mathematical disposition towards learning achievement? International Seminar on Innovation in Mathematics and Mathematics Education (pp. 1-6). Yogyakarta: UNY Press.

Aula, M. F., Suyitno, H., \& Rosyida, I. (2019). Mathematical literacy ability viewed from student's learning style based on gender differences on pbl assistance project assessment. Unnes Journal of Mathematics Education Research , 8(1): 96-103.

Baer, J. \& Kaufman, J. C. (2008). Gender differences creativity. Journal of Creative Behavior . 
Birenbaum, M. \& Nasser, F. (2006). Ethnic and gender differences in mathematics achievement and in dispositions toward the study of mathematics. Learning and Instruction, 16(1): 26-40.

Cramond, B., Morgan, J., Bandalos, D., \& Zuo, L. (2005). A repost on the 40-year follow up of the torrence tests of creaive thinking. Gifted Child Quarterly, 49(4): 283-291.

Erdem, E. \& Soylu, Y. (2017). Age-and gender-related change in mathematical reasoning ability and some educational suggestions. Journal of Education and Practice, 8(7): 116-127.

Fauzan, A., Musdi, E., \& Yani, R. (2018). The influence of realistic mathematics education (rme) approach on students' mathematical representation ability. 1 st International Conference on Education Innovation: Advance in Social Science, Education, and Humanities Research (hal. 9-12). Surabaya: Atlantis Press.

Halat, E. (2008). In-service middle and high school mathematics teachers: geometric reasoning stages and gender. The Mathematics Educator , 18(1): 8-14.

He, W. \& Wong, W. (2011). Gender differences in creative thingking revisited: finding from analysis of variability. Personality and Individual Differences , 51(7): 795878.

Herizal, H., Suhendra, S., \& Nurlaelah, E. (2019, February). The ability of senior high school students in comprehending mathematical proofs. In Journal of Physics: Conference Series (Vol. 1157, No. 2, p. 022123). IOP Publishing.

Lestari, K. E. (2015). Analisis kemampuan pembuktian matematis mahasiswa menggunakan pendekatan induktif-deduktif pada mata kuliah analisis real. Jurnal Kajian Pendidikan dan Pengajaran , 1(2): 128-135.

Lowrie, T. \& Diezmann, C. M. (2011). Solving graphics tasks: gender differences in middle-school students. Learning and Instruction , 21(1): 109-125.

Mahama, I., Kwaw, R., \& Mensah, K. (2019). Relationship between creative thinking and students academic performance in english language and mathematics: the moderating role of gender. Journal of Education, Society, Behavioural Science , 31(4): 1-10.

Maya, R. \& Sumarmo, U. (2011). Mathematical understanding and proving abilities experiment with undergraduate student by using modified moore larning approach. IndoMS JME , 2(2): 231-250.

Nurrahmah, A. \& Karim, A. (2018). Analisis pembuktian matematis pada mata kuliah teori bilangan. Jurnal Edumath , 4(2): 21-29.

Rochmad. (2010). Proses berpikir induktif dan deduktif dalam mempelajari matematika. Jurnal Matematika Kreatif-Inovatif, 1(2): 107-117.

Santosa, C. A. (2013). Mengatasi kesulitan mahasiswa ketika melakukan pembuktian matematis formal. Jurnal Pengajaran MIPA , 18(2): 152-160.

Sari, D. P. (2016). Berpikir matematis dengan metode induktif, dedduktif, analogi, integratif, dan abstrak. Jurnal Matematika dan Pendidikan Matematika , 5(2): 7989.

Snowman, J. \& McCown, R. (2012). Psychology applied to teaching, Thirteenth Edition. US: Cengage Learning.

Soedjadi. (2000). Kiat pendidikan matematika di Indonesia. Jakarta: Departemen Pendidikan Nasional.

Stefanowicz, A. (2014). Proof and mathematical reasoning. UK: University of Birmingham. 
Sutiarso, S., Bharata, H., Caswita \& Nurhanurawati. (2019). Kemampuan berpikir divergen pada rumpun alabar dan geometri mahasiswa pendidikan matematika. Bandar Lampung: Unpublished.

Sutiarso, S., Coesamin, M. \& Nurhanurawati. (2018). The effect of various media scaffolding on increasing understanding of students' geometry concept. Journal on Mathematics Education, 9(1): 95-102.

Thlen, L. M. (2016). Malaysian students' performance in mathematics literacy in PISA from gender and socioeconomic status perspectives. The Asia-Pacific Education Researcher, 25(4): 657-666.

Wilhelm, J. (2009). Gender differences in lunar-related scientific and mathematical understandings. International Journal of Science Education, 31(15): 2015-2122.

Zhu, Z. (2007). Gender differences in mathematical problem solving patterns: a review of literature. International Education Journal , 8(2): 187-203. 